DOI https://doi.org/10.18551/rjoas.2017-01.20

\title{
INFLUENCE OF IMAGE, SERVICE QUALITY, TRUST, AND EMPHATY ON REVISIT TO THE TOMB OF GUS DUR IN EAST JAVA, INDONESIA
}

\author{
Jabid Abdullah W.* \\ University of Khairun Ternate, Indonesia \\ Abady Chusnul \\ University of Bhayangkara Surabaya, Indonesia \\ *E-mail: abdullah.wajir@yahoo.com
}

\begin{abstract}
Indonesia is rich with prominent figures tombs with high potential for being religious tourism destination. Mostly those that are respected for their contribution to Islamic religion spreading in early times. In effect, the present society knows them from historical literature, or from the remaining mosques or other buildings. In contrast, most of Indonesian people know Gus Dur directly, as he once the chief of the largest social organization (Nadhlatul Ulama, 1989-1999) and President (1999-2001). Even though he was not spreading Islamic teachings as most Walis had done in early times, many consider him as one, since he brings the messages with him such as equality, democracy, tolerance and strong civil society which are thought as integral part of religiosity. Hence, the study applies relevant variables covering image, knowledge, trust and empathy related to Gus Dur figure that can lead to revisit behavior, and also covers serqual to represent conditions around the tomb as its first purpose. The second one is to explore and compare two frameworks of revisit behavior embedded in the model, those are trust-empathy-revisit behavior and knowledge-empathy-revisit behavior.
\end{abstract}

\section{KEY WORDS}

Image, trust, empathy, knowledge, serqual, revisit behavior.

Several countries in Asia have histories of Islam religion spreading in early times. Prominent figures with undeniable contribution of Islam religion spreading were called wali (s). Wali in Arabic language means ones the God loves for their total devotion (or Sunan in Javanist language, title given to respected figures in $15^{\text {th }}$ and $16^{\text {th }}$ centuries). Their tombs surprisingly become the magnet for tourism. People respect and appreciate their contribution in Islam religion spreading by developing pilgrimage habit to their tomb. This pilgrimage activity itself relates to one of the religion's norms that consider making a journey from one a place to another for obedience to God purpose as a noble thing.

Governments nowadays turn on Walis' tombs for their economic buffer of the government revenues as the number of pilgrims are increasingly growing. Local religious tourism centered on Walis' tombs also has an effect on people's economic dynamism living nearby. It can be in the form of a spontaneous market around the tomb, or others such as homestays, hotels, tour and travel agencies, or kiosk and restaurants. This kind of tourism has a growingly stronger attraction and has prospect to replace nature tourism as a dominant tourism with largest income prospect.

One of those countries blessed with abundant tombs are Indonesia. With so many Wali's tombs scattering across Java and Bali, one that strikes most attention is Gus Dur's. While, thought, Gus Dur has relation to historical Wali, he lived in a much far recent. He died in 2009. Some of the people, instead many do not, believe that Gus Dur was also a Wali. According to them, Gus Dur has several characteristics commonly attached to Wali. His entire life was devoted to improve society position vis-a-vis to government, support democracy, and equality of all social groups that were previously accustomed to segmented and segregated way of life that many believe that Gus Dur brought with him the messages 
from God. Some of the messages are democracy, tolerance, equality, and strong civil society.

One big different separating Gus Dur from most Walis is that so many people has recognized GurDur, as they witnessed his struggle to improve social life his living time. In contrast, all people in Indonesia know Walis only from the historical books and remnants such as tombs and mosques. Most people in Indonesia know well Gus Dur as he was one president in 2009, the grandson of the biggest religion social group known as Nahdlatul Ulama (NU), and once the leader of this organization for three period (1989-1989, 19891994, 1994-1999).

The NU has large members. With this, NU has unavoidably influence in social and political issues. It should be unsurprising that $\mathrm{NU}$ has a political party representing its interests in government known as PKB (nation awakening party). In the middle of reformation movement, by means of this Party, Gus Dur seized power as president in 1999.

Before assuming presidency, Gus Dur has tried to strengthen the position of society vis-à-vis government which was at that time was characterized as building a strict authoritarian power. He intended to form a strong civil society which has capability to develop itself in the face of government which often stifle this prospect to keep it in power

During his presidency, Gus Dur removed all rules that hold down the freedom of certain minority groups. For example, thanks to Gus Dur, Chinese ethnis can perform their religious rituals and customs. He also defended disadvantage small religious groups such as Jemaah Ahmadiah and many others reproached for their deviation from true Islam's principles. During this time, he tried to make a shake-up within government such as, removing some ministries he assumed to be full of inefficiency and corruption, skipping hearing with parliamentary he thought as standing in the way of his plans, and sacking some political party-related ministers. Many high officers and his allies in government felt hurt and fought back against him. As the dissents unite the power, they cooperate to make Gus Dur fall down.

With this as a background, it is reasonable to assume that people commonly has formed image and harbored knowledge of Gus Dur, and trust as well based on reputation Gus Dur has molded during his leadership. Variable empathy is applied to represent people's alleged silent support to Gur Dur. This variable is thought as related to the fact of Gus Dur's tomb largest visitors and their amalgamate nature. The present research tries to apply those variables and design a model to explain revisit behavior among pilgrims to Gus Dur's tomb. To factor in the influence of conditions around the tomb, the research includes variabelserqual. This is especially so as the tomb has special characteristics such as simplicity, far distance between the place and parking lot, and amalgam of pilgrims.

The focus on revisit behavior is based on data from East Java Tourism Office that reveals that the number of pilgrims visiting to Gus Dur's tomb averages 8.000 people a day. It means the number of pilgrims reaches to 150 thousands in a month, the number that exceed the average number visiting other Walis' tombs such the tombs of Sunan Bonang, Maulana Malik Ibrahim, Sunan Ampel, Sunan Drajat, and Sunan Giri in East Java (TRIBUNnews.com Network, 2014).

Sunan Bonang's tomb in Tubanwhich is claimed as a crowded religious destination in East Java only attracts 2,231 million of visitors a year, followed by Maulana Malik Ibrahim's tomb in Gresik with 1,439 million, and Sunan Ampel's tomb in Surabaya with 1,273 million.

All variables in the present study covers the time during, before and after Gus Dur leadership, and condition around his tomb. The study assumes that all variables mentioned above have interplay effect that can lead to revisit behavior today, that is the main aim of this research.

Tourism literature is still thin. It is worsen by the fact that there is still short of research exploring religious tourism by means of quantitative methodology. Religious tourism research is replete with psychological and sociological values alien to management and economics science, and qualitative approach is apt to reveal hidden phenomenon (neumenon). The present study tends to fill the gap, by applying variables worth to be considered by religious tourism management and government, and even entrepreneurs as long as it has relevance. 
Moreover, there is lack of religious tourism literature exploring brand figure. Indonesia is rich with tombs of well-known figures which either has been or can be developed to be tourism destination. Most tourism literature explores issues of worshipping places, religiosity, and government policies.

Variable empathy is commonly found in psychological and sociological literature, and quite rare in tourism literature. Empathy in economic and management terms can play parts for products with which consumers emotionally can relate, especially those that enable them to bring up the values of nationalism, fairness, identity and existence, defending they thought need to be defended, environment awareness, respect, appreciation and others.

Research Questions. With background outlined above, the present study intends to explore the following research questions:

1. Does image, and serqual have direct and significant effect on revisit behavior of pilgrims to Gus Dur's tomb?

2. Does trust have mediating effect to relationship between image and empathy?

3. Does knowledge has mediating effect to relationship between Serqual and empathy?

4. Does empathy has mediating effect to relationship between trust and revisit behavior?

5. Does empathy has mediating effect to relationship between knowledge and revisit behavior?

\section{LITERATURE REVIEW}

Image. Hogan (2005) holds that image of a brand is formed from all sorts of information concerning product, service and company of the brand. Consumers obtain the information from: firstly, direct experience that influence satisfaction and expectation. Brand is not only made to work optimally and provide the base for good performance, but also to grasp and reflect desired values so that fulfill consumers' personal needs, important for the relationship building between them. It is possible so through perception purposely molded by the company owning the brand by means of many kinds of communication. To most of brands, media and environment to which brand is offered to the consumers can communicate the available attributes. All media have role in nurturing positive relation to consumers. For optimal result, all these factors should work synerginatically in such a way that they make a total picture of the brand. This whole picture is called brand image.

Brand image reflects the promises, superiorities and personal characteristic perceived by consumers. Davis (2000) pinpoints that attributes of brand image include brand associations, that is the characteristics that are associated to the brand by consumers, perception of the promises made by the brand, and belief that brand will continuously fulfill consumers' expectation. According to Davis, another equally important element is brand personality, that is variety of human characteristics encapsulated into the brand by consumers, covering personality, characters, gender, size, form, ethnicity, intellegence, socio-economic status, and education. Personalities of the brand determine its strength and weakness amid other brands, its special position in the wilderness of competition, and its chance to win consumers' favor over others. David Ogilvy (in Biel, 1999: 161) in American Marketing Associations (AMA) in 1955 argues that brand image "is the picture people carry around in their heads of a brand, it is the intangible sum of a product's attributes: its name, packaging, and price, its history, its reputation, and the way it's advertised".

Aaker (1991) considers brand image with personalities as a requisite to be accounted as brand equity, and defines a brand as a series of human characteristic associated to the brand. According to Aaker (1997), personalities consist of five dimensions: competence, sincerity, excitement, sophistication, and ruggedness.

Empathy. Early perspective pictures empathy as putting cognitively oneself on other's psychological perspective without involving emotion feeling, or one's effort to grasp other's psychological condition. Spiro (1992) defines empathy as comprising of pity feeling, sincerity, and respect to other. Affective feeling put forward by Hoffman (1984) and Eisenberg and Strayer (1987) describes emphaty as a affective response, or emotional response, to other 
people suffered by certain problem. Batson et al. (2002) enriches this affective definition by emphasizing that affective reaction to other people suffered by certain people as an empathy feeling. According to them, emphaty motivates people to help others in need.

To settle this cognitive and affective debates over empathy definition, Davis (1983, 1996) argues that emphaty is a multi-dimension process, involving a set of intertwined constructs. He defines empathy as a cognitive process in putting oneself on other's perspective (perspective taking), as affective experience in providing affective attention, and as affective experience in the form of worry or distress (personal distress). Perspective taking and role taking refer to the process during which an observer tries to comprehend other through bonding perception, be it kinship, friendship, acquaitance, commonness, or imagination of other's perspective.

Emphaty attention and personal distress refer to experience someone has in responding to other people's experience. Emphatic attention is emotional reaction in the forms of pity, sympathy, gentility and concern about other people. Personal distress refers to inclination for one to experience anxiety, tension, and uneasiness as seeing other's pressure and uncomfort. Drawing on Batson's theory, Davis finds that perspective taking and emphatic attention are positively related and that personal distress and emphatic attention are negatively related.

For the purpose of the study, the present study applies variable constructs covering perspective taking and role taking from Davis (1980) and McBane (1995).

Trust. Gefen, Karahanna and Straub (2003b) take trust as a set of beliefs in ability, benevolence, and integrity of the trustee as distinct from consumers' behavioral intentions. Characteristics of brand leading to trust include predictability, having reputation and being competent. For the purpose of study, the present study applies three constructs from Aaker, DA and Alvarez del Blanc, RM., 1995; Lassar, W., Mittal, B., and Sharma, A., 1995; and Yoo, B., Donthu, N., and Lee, S., 2000 representing all elements above.

Knowledge. Knowledge are comprised of two dimensions, namely familiarity and past experience. Millman and Pizam (1995) applies prior visitor number as a measure of familiarity and find that familiarity has a significant effect on the desire and intention to visit a destination. A study examining the reasons driving Arabian people to visit Europe finds that familiarity is the main one (80\% respondent) (Hales and Shams, 1990).

Past experience is among factors with significant influence on decision-making process. Bettman and Park (1980) prove that consumers who do not have prior experience make harder consideration in decision-making process than otherwise.

This study follows the constructs from Wang et al (2009). The variable consists of four construct representing knowledge, familiarity, and past experience.

Service Quality. Service quality has been identified as an important factor in building competitive edge and superiority. Parasuraman et al. (1985) list ten determinants of service quality (reliability; responsiveness; competency; acess; hospitality; communication; credibility; security; understanding consumers; andtangibles). They then makes a simpler five dimensions of SERVQUAL (Parasuraman et et al., 1988, 1991), those are:

1. Tangibles, referring to physical facilities, equipments, personnel and communication means;

2. Reliability, ability to provide service as promised accurately and reliably;

3. Responsiveness; quick in responding complaints and handling problems;

4. Assurance, referring to knowledge and hospitality necessary in building trust and belief; and

5. Empathy, referring to special attention to consumers.

This study applies constructs of Serqual from Parasuraman et al $(1988,1991)$ representing all this elements. This variable consists of five constructs.

Loyalty. The most - researched dimension of loyalty isrepurchase intentions and wordof-mouth (Swan and Oliver, 1989; Zeithaml, 2000; Zeithaml et al., 1996).Consumers' loyalty on a certain service or firm (Andreassen and Lindestad, 1998). Buying continuously, using a service repeatedly, and spreading positive word-of-mouth are main indicators of consumers' loyalty (Andreassen and Lindestad, 1998; Selnesand Hansen, 2001; Zeithaml, Berry, and 
Parasuraman, 1996). For the purpose of study, the study chooses the first indicator with adaptation, namely revisit. The indicators are taken from several researchers, including Zeithaml et al., 1996; Srinivasan et al., 2002, and McKinny et al., 2002).

\section{RESEARCH CONCEPTUAL FRAMEWORK}

Research Conceptual Framework. Conceptual framework is designed to provide a clear description as to which variables standing as independent, dependent and mediating. These positions, relations among them, and hypothneses on which to sustain them are based on existing theretical and empirical studies. They are analytically elaborated as following.

Image, Service Quality and Loyalty. Image is generally defined as overall impression visitors have on a certain destination (Rynes, 1991). Image is considered as a relevant factor in a final evaluation of a service (Bitner, 1995; Gronroos, 1984). Moreover, literature concerning service has formed a strong relation between image and perceived service quality (Flavian et al., 2009). Previous reseaches have confirmed (Cheng, T., Lai, L., and Yeung, A. 2008), (Hu, H.H.S., Kandampully, J., and Juwaheer, T.D. 2009), and (Ladhari, R., Souiden, N., and Ladhari, I. 2011). Literature has shown ample evidence on the potential effect of perceived service quality has on consumers' future behavior (Rust and Oliver, 1994; Taylor and Baker, 1994).

In specifying antecedents of loyalty, researchers consider image as a significant component. Fredericks and Salter (1995) consider image along with price, innovation and service quality determine the level of loyalty. In the same vein, European Satisfaction Index (EPSI) includes image as determinants affecting service value and consumers's loyalty (Eskildsen et al., 2004). A destination needs a positive image to hold its market-share (Crompton, 1979).

However, relation between image and loyalty have mixed results: Sirgy and Samli (1985) report that there is direct relation between image and loyalty. Bloemer et al. (1998) study in banking industry reveal indirect relation where the influence of image is mediated by service quality. In tourism field, Kandanpolly and Suhartanto (2000) find that image constitutes as one of two most important factors in determining repurchase and revisit.

Empathy and Loyalty. Few studies have explored relationship between empathy and loyalty. Shin et al (2011) have shown significant relation of empathy and luxury brand loyalty. Taute et. al. (2011) confirm that empathy can lead to behavioral intention. Kim et al (2007) show that empathy drives Japanese tourist keep flowing to Korea to see drama shooting sites.

Trust, Empathy and Loyalty. Most of the existing researches confirm relation between trust and loyalty. Garbarno and Johnson (1999); Chaudhuri and Holbrook (2001) emphasize the importance of building trust as determining consumers loyalty. Roodurmun and Juwaheer (2010) hold that destination loyalty is influenced by trust, and that tourists tend visit destination that they see trusting and reliable (Ekinci and Hosany, 2006). Destination can build a strong emotional relationship with consumers, which in turn can lead to stronger loyalty (Hsu and Liping, 2009).

Only small body of research reveal the gap between trust and loyalty. Valvi and West (2013) exploring the relationship between e-trust and e-loyalty find trust does not necessarily lead to loyalty. In their study, they think it may due to customers' fear of online fraud, as buying online is not secure (Hoffman et al., 1999). As a result, online customers are harder to trust an online transaction compared to offline. Andreasse and Lindested (1997) exploring loyalty in B2B environment in Australian SMEs find no significant relationship between trust and loyalty. Shainesh (2012), exploring the effect of trustworthiness and trust to loyalty, only find the association is partially supported. Herington and Weaven (2007) also find no association between trust and loyalty. This small fragment of researches lend a base for the present research to explore the effect of trust on loyalty in religious tourism field. 
The present study observes that trust mostly engender emotional results such at attachment, commitment, affect, intimacy and others that are prerequisite for repurchase or revisit. Trust it self is cognitive and affective attitude that is close to emotive feeling.

This study puts forward empathy variable to mediate relationship between trust and loyalty. Some works have shown relationship between trust and empathy. One obvious example is the work of Boitor (2012) who proves relation between relationship trust and relationship intention which can be identified as loyalty, mediated by empathy.

Knowledge, Empathy and Loyalty. Different from trust where the bulk of researches prove significant relationship between trust and loyalty and small part prove otherwise, those exploring one of knowledge and loyalty provide somewhat mixed results. They quite depend on the nature of company, industry, types of consumers and markets.

Despite many researches reveal significant relationship between knowledge and loyalty, a similar share of the body reveal the opposite. For instance, Yang and Wang (2010) exploring relationship between consumers' knowledge and loyalty to a store composing three stores selling products of respectively higher quality and higher price, of medium quality and priced, and lower quality and priced show that knowledge does not have direct effect on individual store loyalty and on general store loyalty as well. Jamal and Anastasiadou (2009) explore the relationship between consumers' expertise and loyalty in banking service sector. They define expertise as consumers' ability to perform product/service related tasks successfully and their understanding of and knowledge about various attributes in a product/service category (Alba and Hutchinson, 1987; Jamal and Al-Mari, 2007; Jamal and Naser, 2002; Sheth et al., 1999). They find that knowledge does not have a direct effect on loyalty, which means that a higher knowledge on the part of consumers regarding to the service might lead to decreased loyalty. It lends support from Wirtz and Mattila's (2003) thinking that individuals with the higher levels of knowledge and expertise would have lower risk perceptions and switching costs, and hence, would exhibit decreased loyalty levels. Partial effect is also found in some parts of researches. Lee and Hsu (2010), for example, who explore the effect of brand knowledge on retail service brand loyalty find a partial correlation of the two for convenience store, but significant correlation for cosmetic store.

This study puts forward empathy variable to mediate relationship between knowledge and loyalty. Some works have shown the relationship. One obvious example is the work of Shin et al (2011). While they have shown significant relation between empathy and luxury brand loyalty, they also prove that other variables along empathy including congruity with internal self which can be identified as consumer's familiarity have effect on luxury brand loyalty through empathy as a mediator. Human et al (2011) have shown significant relationship between brand knowledge, brand affect and brand loyalty. They define brand affect as the ability of the brand to evoke positive feelings and emotions from consumers in which empathy might be classified.

Image and Trust. Many studies have confirmed the relationship between image and trust. (Lin and Lu, 2010) surveying consumers of online tour agencies in Taiwan identify that corporate image composed of institutional image, functional image and commodity image all have significant effect on loyalty. In similar vein vein, Hog et al (2010) confirm that Islamic bank image in Malaysia have significant effect on Islamic bank trust (Chen and Phou, 2013) show that there is relationship between destination image and destination trust. It can be inferred that image might lead to trust.

Serqual and Knowledge. Some works already confirm relationship between serqual and knowledge. Sreejesh et al (2015) imply the relationship between serqual and knowledge through the application of service innovativeness, self-congruity, and functional congruity which is moderated by prior experience. O'Neil and Palmer (2005) have shown the relationship between Serqual perception and experience which is part of consumers' knowledge. Otim and Grover (2006) have explored the effect of post-purchase service which implies relation between serqual perception and experience and knowledge on repeat purchase intention. Thus it can be inferred that relationship between Serqual and knowledge has been well established. 


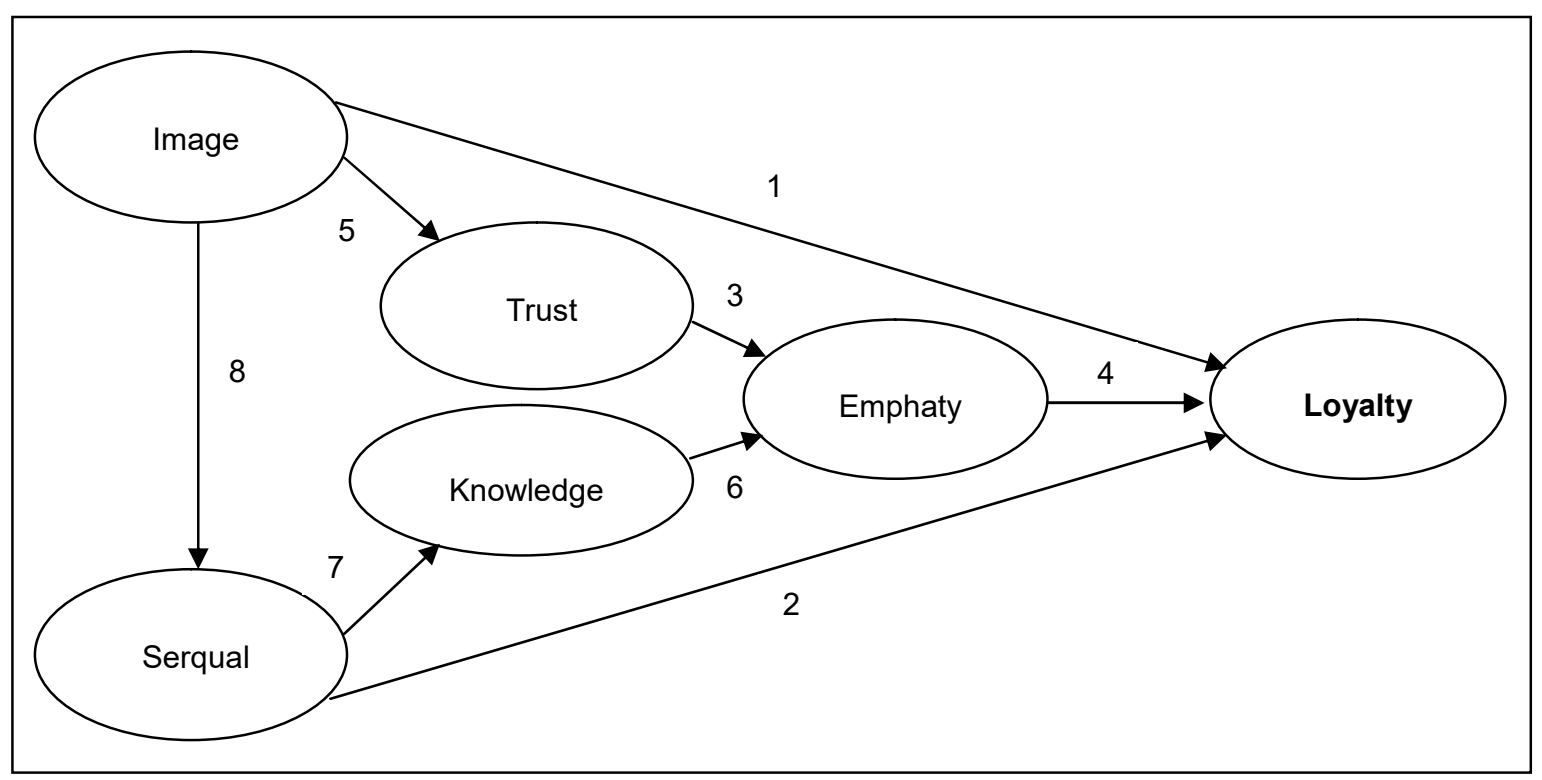

Sources: Faullant et al. (2008), Giovanis et al. (2014), Feng et al. (2003), Shin et al. (2011), Chen \& Phou (2013), Schwartz (2002), Jingjun et al. (2011), Castro et al. (2007)

Figure 1 - Research Conceptual Framework

Research Approach. This research falls into causal study as it intends to explore the effects and causal relationships among applied variables through hypotheseses testing (Sekaran and Bougie, 2013). Especially, it intends to explore and analyze the interplay relations among variables covering image, knowledge, serqual, an trust that can lead to revisit behavior among the pilgrims of Gus Dur, tomb in Jombang Regency. Hence, it applies quantitative method as it fits best to its main purpose.

The survey will be carried out at Gus Dur's tomb in Jombang Regency. The population covers all pilgrims present at the time survey conducted. The average number of pilgrims is 3,000 . Early survey will be conducted for 7 days that the whole population amounts to 21.000 .

To get the right sampling, the present study applies quota as its sampling method. To arrive at the right sampling number, Slovin formula serves best the purpose (Sekaran and Bougie, 2013). The formula is as follows:

$$
n=\frac{N}{1+N(e)^{2}},
$$

where: $\mathrm{n}=$ Sample size; $\mathrm{N}=$ Population size; $\mathrm{e}=$ Leniency percentage is as much as $10 \%$.

Based on the formula, the appropriate sampling number for the study should be as follows:

$$
n=\frac{21.000}{1+21.000\left(0,1^{2}\right)} n=99,5
$$

The above number lead to 100 . The present study consider 100 as its most appropriate number for the sampling.

The present study applies 5-point Likert scale ranging from highly disagree to highly agree (Sekaran and Bougie, 2013).

For instrument validity, the research applies factor confirm a tory factor based on the results of convergent validity and discriminant validity. For reliability, alpha Cronbach constitutes adequate reliability. SEM PLS enables for the study to perform the test of both. Besides, the tool is appropriate for prediction purpose which is important part of the study. 
Table 1 - Appendix A: The Constructs of Variables

\begin{tabular}{|c|c|c|}
\hline Variables & Constructs & Sources \\
\hline Image & $\begin{array}{l}\text { 1. Gus Dur has always a good impression } \\
\text { 2. Gus Dur has a good image } \\
\text { 3. Gus Dur has a better image than other figures }\end{array}$ & $\begin{array}{l}\text { Nguyen and Le Blance, } \\
\text { G., } 2001\end{array}$ \\
\hline Knowledge & $\begin{array}{l}\text { 1. I am aware of Gus Dur's thoughts } \\
\text { 2. I understand Gus Dur's attitude } \\
\text { 3. I understand the background and direction of Gus Dur's } \\
\text { thoughts } \\
\text { 4. I follow all of Gus Dur' struggle }\end{array}$ & Wang et. al., 2009 \\
\hline Serqual & $\begin{array}{l}\text { 1. All Physical facilities around the tomb are convenient } \\
\text { 2. The arrangement for the incoming and going-out pilgrims is } \\
\text { positive } \\
\text { 3. The arrangement of visiting hours is positive. } \\
\text { 4. The layout of all physical building is positive. } \\
\text { 5. The security around the place is positive }\end{array}$ & $\begin{array}{l}\text { Parasuraman et al, 1986; } \\
1991\end{array}$ \\
\hline Trust & $\begin{array}{l}\text { 1. I trust Gus Dur } \\
\text { 2. I consider Gus Dur's thought as appropriate } \\
\text { 3. I see Gus Dur's thoughts can potentially be solution to } \\
\text { nation's major issues }\end{array}$ & $\begin{array}{l}\text { Aaker, DA and Alvarez del } \\
\text { Blanc, RM., 1995; Lassar, } \\
\text { W., Mittal, B. and Sharma, } \\
\text { A., 1995; Yoo, B., Donthu, } \\
\text { N., and Lee, S., 2000. }\end{array}$ \\
\hline Empathy & $\begin{array}{l}\text { 1. I particularly sensitive to pressures Gus Dur went through } \\
\text { 2. The pressures Gus Dur went through disturb me } \\
\text { 3. I understand Gus Dur's position when he got pressured } \\
\text { 4. I understand Gus Dur more by imagining myself in his } \\
\text { position. } \\
\text { 5. When he got pressured it looks as if me who got pressured } \\
\text { 6. I feel contribute to Gus Dur by supporting his thoughts. } \\
\text { 7. It is hard to accept other ways of thingking different from } \\
\text { Gus Dur's }\end{array}$ & $\begin{array}{l}\text { McBane, 1995; Davis, MH, } \\
1980\end{array}$ \\
\hline $\begin{array}{l}\text { Revisit } \\
\text { behavior }\end{array}$ & $\begin{array}{l}\text { 1. I like visiting Gus Dur' s tomb better than others } \\
\text { 2. I intend to keep visiting Gus Dur's tomb as condition permits } \\
\text { 3. I will recommend this destination when I join in a tour group. }\end{array}$ & $\begin{array}{l}\text { Srivivasan et al., } 2002 ; \\
\text { McKinny et al. } 2002\end{array}$ \\
\hline
\end{tabular}

\section{FINDINGS OF RESEARCH}

Based on literature review, it can be seen that image has direct effect on revisit behavior. But through trust and empathy, the relationship between image and revisit behavior is stronger. It also holds to relationship between serqual and revisit behavior, where knowledge and empathy variables strengthen the relationship. For the case of Gus Dur's tomb, it is seen that empathy in latter case plays a bigger role that the former as bulk of literature has confirmed relation between knowledge, empathy and loyalty. Contrary to this, for former case only few studies confirm relationship between trust, empathy and loyalty.

Knowledge has proven to be more susceptible to bring up empathy, which together might lead to loyalty as many studies have confirmed. In Gus Dur's case, knowledge on Gus Dur's struggle during pre-presidency, presidency, and post-presidency provide a bigger propensity to bring up empathy among people living during those times. Many studies, however, show that knowledge does not necessarily lead to loyalty, such as Jamal and Anastasiadou's study (2009), Yang and Wang's (2010) and others.It is then seen that empathy serves full mediation in the relationship between knowledge and revisit behavior.

In the same vein, trust does not necessarily lead to loyalty, as several studies have shown such as Valvi and West's (2013), Shainesh (2012), Andreassen and Lindested (1997), Herington and Weaven (2007) and others. Many studies have confirmed that relationship between trust and loyalty is more established than that between knowledge and loyalty. It is so due to the nature that trust tends to engender emotional attachment, commitment, and connectedness that are prerequisite for loyalty. It is then seen that empathy serves partial mediation in the mediation between trust and loyalty. 


\section{DISCUSSION OF RESULTS}

For tourism involving figures as central magnet usually provide knowledge and trust for the people to consider revisiting. However, there is not assurance that both respectively determine people to revisit. Many studies have shown that there are no significant relationship between knowledge and loyalty, and trust and loyalty. While other factors might play parts, for prominent figures whose fight for social interest many people witness during their living times, empathy might play significant role.

Even the relation with loyalty is positive, knowledge and trust play part in the different weight in people's consideration to revisit. Trust tends to engender emotions and feeling such as emotional attachment, commitment, and connectedness that are prerequisite for loyalty. It means that trust is more able to skip empathy to arrive at loyalty than knowledge. It is seen then that empathy serves partial mediation in the relation between trust and revisit behavior, and serves full mediation in the relation between knowledge and revisit behavior.

If it is the case, than manager and administrator of prominent figure-based tourism destination should prioritize knowledge over trust by for example building museum and library related to the concerned figure, an institution to maintain figure's ideas and ideals, printing books concerning figure's biography and his/her ideas and others most of which have been materialized in Gus Dur's case. It might explain the large number of pilgrims visiting Gus Dur's tomb compared to other Walis' tombs.

Empathy might play a much lesser part for figures who lived at historic time when many current people are not present to witness. In this case, trust might have a bigger weight that knowledge for people to consider to revisit.

\section{CONCLUSION}

Empathy can be applied in loyalty framework in tourism sector, as long as figure, place, or nature-based tourism destination has concurrent time relation with people as its consumers. Gus Dur provides image, trust, and knowledge for people to revisit, and condition of serqual that is made to reflect Gus Dur's personality, reputation, and nationwide respect to his struggle and contribution to nation advancement. Since many people witness directly Gus Dur' struggle, empathy plays a significant part, and can serve a mediation to relation between trust and revisit behavior and that between knowledge and revisit behavior. For the former, empathy serves a full mediation, while the latter it serves partial mediation. For place or nature-based tourism destination, empathy can be applied to the place where people have concurrent time relationship, such as bombing area in Bali, or area with tsunami experience in Aceh and others.

\section{REFERENCES}

1. Aaker, D.A. (1991). Managing Brand Equity: Capitalizing the Value of a Brand Name. Free Press, New York.

2. Dimensions of Brand Personality (1997). Journal of Marketing Research, 34, 347-357.

3. Aaker, D.A. and Alvarez del Blanco, RM. 1995. Estature de la marca: medir el valor por productosy mercados. Harvard Deusto Business Review, No. 69, Nov-Dec. pp. 74-87).

4. Alba, J.W \& J.W. Hutchinson. 1987. Dimensions of customer expertise. Journal of Consumer Research, 13, 411-454.

5. Andreassen, W. and Lindestand, B. 1998. Customer Loyalty and complex service. The impact of corporate image on quality, customer satisfaction and loyalty for customers with varying degrees of service expertise. International Journal of Service Industry Management, Vol. 9, No. 1, pp. 7-23.

6. Barroso, C., Armario, E.M., Ruiz, D.M. 2007. The Influence of Market Heterogeneity on The Relationship Between a Destination's Image and Tourists Future Behavior. Tourism Management 
7. Batson C.D., Chang J., Orr, R and Rowland, J. 2002. Empathy, attitudes and action: can feeling for a member of a stigmatized group motivate one to help the group. Personality and Social Psychology Bulletin, 28, 1656-1666.

8. Bettman, J.R and Park, C.W. 1980. Effects of prior knowledge and experience and phase of the choice process on consumer decision: a protocol analysis. Journal of Consumer Research, Vol. 7, Dec. pp. 234-47.

9. Bitner, MJ. 1995. Building service relationships: It's all about promises. Journal of the Academy of Marketing Science, Vol. 23 No. 4, pp. 246-51.

10. Bloemer, J., De Reyter, K. and Peeters, P. 1998. On the Relationship Between Store Image, Store Satisfaction and Store Loyalty. European Journal of Marketing. 32, 499513.

11. Boitor, C. 2012. The Effects of Relationship Trust on Prosocial Intentions and Behavior in Adolescents: Exploring the Role of Empathy and Exploration Behavior. Dissertation.

12. Chauduri A., Holbrook, HB. 2001. The Chain of Effects from Brand Trust and Brand Affect to Brand Performance: The Role of Brand Loyalty. J Mark, 65 (2): 81-93.

13. Chen, Ching-Fu, Phou, S. 2013. A Closer Look at Destination: Image, Personality, Relationship and Loyalty. Tourism Management.

14. Cheng, T., Lai, L. and Yeung, A. 2008. The driving forces of customer loyalty: a study of internet service providers in Hong Kong. International Journal of E-Business Research, Vol. 4 No. 4, pp. 26-42.

15. Crompton, J.L. 1979. An Assessment of the image of Mexico as a vacation destination and the influence of geographical location upon that image. Journal of Travel Research. 17, No. 14: 18-23.

16. Davis, M.H. 1983. Measuring individual differences in empathy: evidence for a multidimensional approach. Journal of Personality and Social Psychology. 44, 113-136.

17. Davis, S.M. 2000. Brand Asset Management: Driving Profitable Growth through Your Brand. Jossey-Bass, Inc. Publisher, California.

18. Davis, MH. 1996. Empathy: a social psychological approach. Madison, WI: Westview Press

19. Davis, MH. 1980. A multidimensional approach to individual differences in empathy. Catalog of selected documents in Psychology, No. 85.

20. Davis, MH. 1996. Empathy: a social psychological approach. Madison, WI: Westview Press.

21. Eskildsen, J.K, K. Kristensen, H.J. Juhl, and P. Osterguard. 2004. The drivers of customer satisfaction and loyalty. Total Quality Management \& Business Excellence 15, No. 5 \& 6: 859-68.

22. Rita, F., Kurt, M., and John, F. 2008. The Impact of Satisfaction and Image on Loyalty: The Case of Alpine Ski Resorts. MSQ Emerald.

23. Eisenberg, N. \& Strayer, J. 1987. Empathy and its development. Cambridge: Cambridge University Press.

24. Feng, J., Lazar, J., and Jenny, P. 2003. Interpersonal Trust and Empathy Online: A Fragile Relationship.

25. Flavian, C., Tores, E., and Guilaniu, M. (2009). Corporate Image Measurement: A Further Problem for the Tangibilization of Internet Banking Service. The International Journal of Bank Marketing.

26. Frederick J.O. and Slater, J.M. 1995. Beyond customer satisfaction. Management Review, Vol. 84, No. 5, pp. 29-33.

27. Garbarno and Johnson. 1999. The Different role of Satisfaction, Trust, and Commitment in Customer Relationships. Journal of Marketing.

28. Geovanis, N., Zondiros, D., Tomaros, P. (2014). The antecedents of Customer Loyalty for Broadband Services: The Role of Service Quality, Emotional Satisfaction and Corporate Image. Procedia-Social and Behavioral Sciences.

29. Gefen, D., \& Karahanna, E., \& Straub, D. W., 2003b. Trust and TAM in online shopping: an integrated model. MIS Quarterly. 27 (1), 51-90. 
30. Gronroos. (1984). A Series Quality model and Its Marketing Implications. European Journal of Marketing, 18 (4), 36-44.

31. Hoffman, M.L. 1984. Empathy, its limitation, and its role in a comprehensive moral theory. In W.M. Kurtines \& J.L. Gewirtz (Eds). Morality, Moral Development and Moral Behavior (pp. 283-302). Hillsdale, NJ: Eribaum.

32. Hog, MZ., Sultana, N., and Amin, M., (2010). The Effect of Trust, Customer Satisfaction and Image on Customers Loyalty in Islamic Banking Sector. South Asian Journal of Management, 17, 1.

33. Hu, H-H., J. Kandampully, and T.D. Juwaheer. 2009. Relationship and impacts of service quality, perceived value, customer satisfaction, and image: an empirical study. The Service Industries Journal, 29, No. 2: 111-125.

34. Herrington, C., and Weaven, S. 2007. Can banks improve customer relationships with high quality online services? Managing Service Quality, Vol. 17 No. 14, pp. 404-27.

35. Hoffman, D.L., T.P. Novak and MA Peralta. 1999. Information privacy in the market place: implications for the commercial use of anonymity on the Web. Information privacy in the marketplace. Information Society. Vol. 15 No. 2: 129-139.

36. Hoffman, M.M. 1984. Interaction of affect and cognition in empathy. In CE Izard, J. Kagan \& R.B. Zajon (Eds). Emotions, cognition and behavior (pp. 103-134). New York, Cambridge University Press.

37. Hogan, S., Almquist, E. and Glym, S. 2005. Brand building: finding the touchpoints that count. Journal of Business Strategy. 21: 11-18

38. Hsu C., and Liping A.C. 2009. Brand knowledge, trust and loyalty - a conceptual model of destination branding. In Hospital and Tourism Management, International CHRIE Conference -Referred Tract year 2009.

39. Human, G., Evans, Sounter, and Xabanisa. 2011. Advertising, Brand Knowledge and Attitudinal Loyalty in Low-Income Markets: Can Advertising Make a Difference at the Bottom-of-the Pyramid?. Management Dynamic. 20 (2).

40. Jamal, A and Al-Mari, M. 2007. Exploring the effect of self-image congruence and brand preference on satisfaction: the role of expertise. Journal of Marketing Management, Vol. 23 Nos 7/8, pp. 613-30.

41. Jamal, A. and Nasser, K. 2002. Customer satisfaction and retail banking: an assessment of some of the key antecedents of customer satisfaction in retail banking. International Journal of Bank Marketing, Vol. 20 No. 4, pp. 146-160.

42. Jingjun, Benbasat, I., Fetelli, R.C. 2011. The Effects of Service and Consumer Product Knowledge on Online Customer Loyalty. JAIS. 12 (11).

43. Kandanpolly and Suhartanto. 2000. Customer Loyalty in The Hotel Industry:The Role of Customer Satisfaction and Image. International Journal of Contemporary Hospitality Management.

44. Kim, SS., Agrusa, J., Lee, H., and Chon, K. 2007. Effects of Korean Television DramasonThe Flow of Japanese Tourists. Tourism Management, 28.

45. Kini, Y and Hosany, S. 2006. Destination personality: an application of brand personality to tourism destination. Journal Travel Research. 45 (2): 127-129.

46. Ladhari, R., Soviden, N. and Ladhari, I. 2001. Determinants of loyalty and recommendation: the role of perceived service quality, emotional satisfaction and image. Journal of Financial Service Marketing, Vol. 16, No. 2, pp. 111-124.

47. Lassar, W., Mittal, B. \& Sharma, A. 1995. Measuring customer based brand equity. Journal of Consumer Marketing, 12 (4), 11-20.

48. Lee, KY., and Hsu, YC. 2010. Communication and Brand Knowledge as Determinants of Retail Service Brand Loyalty - An Empirical Test in a Multiple Retail Service Brand Context. Journal of Global Business and Technology. 6 (1).

49. Lin, LY. and Lu, C.Y. 2010. The Influence of Corporate Image, Relationship Marketing, and Trust on Purchase Intention: The Moderating Effects of Word-Of-Mouth. Tourism Research, 65 (3).

50. McBane, Donald A. 1995. Empathy and the salesperson: a multidimensional perspective. Psychology \& Marketing, 12 pp. 349-369. 
51. McKinny, V., Yoon, K., and Zabedi, F. The measurement of web-customer satisfaction: an expectation and disconfirmation approach. Information Systems Research (13:3), 2002, pp. 296-315.

52. Milman, A. dan Pizam, A. 1995. The role of awareness and familiarity with a destination: the central Florida case. Journal of Travel Research, Vol. 33, No. 3, pp. 21-27.

53. Nguyen N., LeBlanc C. 2001. Image and reputation of higher education institutions in students' retention decisions. International Journal of Educatinal Management, Vol. 15 Issue 6 pp. 303-311.

54. O'Neill and Palmer, A. (2005). An Exploratory Study of the Effects of Experience on Consumer Perceptions of the rvice Quality Construct. Managing Service Quality, 13, 3.

55. Otim, S. and Grover, V. (2006). An Empirical Study on Web-Based Services and Customer Loyalty. European Journal of Information System, 15.

56. Parasuraman, A., A. Berry, L.L. and Zeithaml, V.A. 1991. Refinement and Reassessment of The Serqual Scale. Journal of Retailing, Vol. 67 No. 4, pp. 420-50

57. Parasuraman, A., Zeithaml, V.A., and Berry, LL. 1988. SERQUAL: A multiple item scale for measuring consumer perceptions of service quality. Journal of Retailing, 64:12-40.

58. Parasuraman, A., Zeithaml, V.A. and Berry, L.L. 1986. SERQUAL: A multiple-item scale for measuring customer perceptions of service quality. Report. Marketing Science Institute No. 86-108. August.

59. Parasuraman, A., Zeithaml, V.A., and Berry, L.L. 1985. A Conceptual model of service quality and its implications for future research. Journal of Marketing, Vol. 49, pp. 41-50

60. Rust and Oliver. (1994). Service Quality: New Directions on Theory and Practice. Sage Publication. London.

61. Rynes, S.L. 1991. Recruitment, Job Choice, and Post-Hire Consequences: A Call for New Research Directions. Hanbook of Industrial and Organizational Psychology.

62. Schwartz, Wynn. (2002). From Passivity to Competence: A Conceptualization of Knowledge, Skill, Tolerance, and Empathy. Psychiatry.

63. Sekaran, Uma, dan Roger Bougie. 2013. Research Methods for Business: A SkillBuilding Approach 6th Edition. Wiley \& Sons Ltd.

64. Shainesh, G. 2012. Effects of trustworthiness and trust on loyalty intentions: validating a parsimonious model in banking. International Journal of Bank Marketing. Vol.30 No. 4, pp. 267-77.

65. Sheth, Jagdish, N., Mittal, Banwari and Newman Bruce. 1999. Customer Behavior: Customer Behavior and Beyond. Orlando, Florida. The Dryden Press.

66. Shi, Y., Prentice, C., He, W.2014. Linking Service Quality, Customer Satisfaction and Loyalty in Casinos, Does Membership Matter?. International Journal of Hospitality Management.

67. Shin, J., Min-Shook, P., Mi-Ri, K. 2011. The Study on the Dimension of Experiential Consumption of Luxury Brands. Journal of Business and Educational Leadership, 3 (1).

68. Sirgy, M.J. and Samli, A., 1985. A path analytic model of store loyalty involving self concept, store image, socioeconomic status, and geographic loyalty. The Journal of the Academy of Marketing Science, 13, pp. 265-291.

69. Spiro, H. 1992. What is empathyand can it be taught. Annals of Internal Medicine, 116, 843-846.

70. Srivinasan, S.S., Anderson R., and Ponnavolu, K. 2002. Customer loyalty in ecommerce: an explosion of its antecedents and consequences. Journal of Retailing, Vol. 78, pp. 41-50.

71. Sreejash, Mitra, and Sahoo. 2015. The Impact of Customer's Perceived Service Innovativeness on Omage Congruence, Satisfaction and Behavioral Outcomes. Journal of Hospitability and Tourism Technology, 6 (3).

72. Strayer, J., \& Eisenberg, N. 1987. Empathy is viewed in context. In N. Eisenberg \& J. Strayer (Eds.), Empathy and Its Development (pp. 389-398). New York: Cambridge University Press. 
73. Swan, J.E., and W.S. Martin. 1980. Testing comparison level and predictive expectations model of satisfaction. Advances in Consumer Research Proceedings, Vol. 8, Eleventh Annual Conference (Oct.): 77-81.

74. Taylor and Baker. (1944). An Assessment of The Relationships Between Service Quality and Customer Satisfaction in The Formation of Customer's Purchase Intention. Journal of Retailing.

75. Taute, H.A., McQuitty, S. and Sauter, E.P. 2011. Emotional Information Management and Responses to Emotional Appeals. Journal of Advertising, 40 (3).

76. Valvi, C.A. and West, C.D. 2013. E-Loyalty is not all about trust, price also matters: extending expectation-confirmation theory in bookselling websites. Journal of Electronics Commerce Research, Vol. 14, No. 1, pp. 99-123.

77. Wang, C-C., Chen C-C, and Jiang, J-C. 2009. The impact of knowledge and trust on Econsumers' online shopping activities: an empirical study. Journal of Computers, 1(4).

78. Wirtz, J. and Matilla, S.A. 2003. Customer response to intangible and tangible service factors. Journal of Service Marketing, Vol. 17 No. 17 pp. 649-65.

79. Yang D. and Wang, $X$. The effects of 2-tier store brands' perceived quality, perceived value, brand knowledge and attitude on store loyalty. Front. Bas-Res. China. 2010.

80. Yoo, B. et al 2000. An examination of selected marketing mix elements and brand equity. Journal of The Academy of Marketing Science, 28(2), 195-211.

81. Zeithaml, Valerie A., Leonard L. Berry, and A., Parasuraman. 1996. The Behavioral Consequences of Service Quality. Journal of Marketing, Vol. 60 (4): 31-46.

82. Zeithaml, V.A. 2000.Service Quality, profitability, and the economic worth of customers: what we know and what we need to learn. Journal of the Academy of Marketing Science. Vol. 28, No. 1, pp. 67-85. 